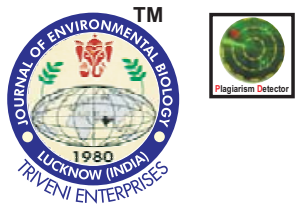

\title{
Impact of wastewater irrigations and planting methods on leaf firing, colour, quality and traffic tolerance of turfgrass
}

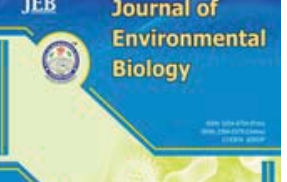

\section{Authors Info}

\section{D.S. Gurjar* and R. Kaur}

Water Technology Centre, ICAR-Indian Agricultural Research Institute, New Delhi-110 012, India

*Corresponding Author Email : dsgurjar79@gmail.com

\section{Key words}

Planting method

Turfgrass

Traffic tolerance

Wastewater irrigation

Publication Info

Paper received : 01.06.2017

Revised received : 09.08.2017

Re-revised received: 19.08 .2017

Accepted : 29.08.2017

\section{Abstract}

Aim : Impact assessment of wastewater irrigations on growth and quality of turfgrass under planting with or without plastic base may be provided the information for feasibility of wastewater use in turf/lawn grass.

Methodology : Turfgrass (Cynodon dactylon L. var. selection-1) was planted under two planting methods (with plastic base and without) during 2013. Treatments were taken as three wastewater irrigation schedules of crop evapotranspiration (ETc, at 75,100 and $125 \%$ and one control as groundwater irrigations at $100 \%$ ETc). The experiment was laid-out in randomized block design with three replications. Data were recorded on leaf firing, colour, quality and traffic tolerance of turfgrass continuously for 3 years (2013-16) through rating based monthly visual observations.

Results : Monthly ratings on leaf firing, colour, quality and traffic tolerance of turfgrass were stated that leaf firing percentage was high during winter months and low in summer months. Ratings on

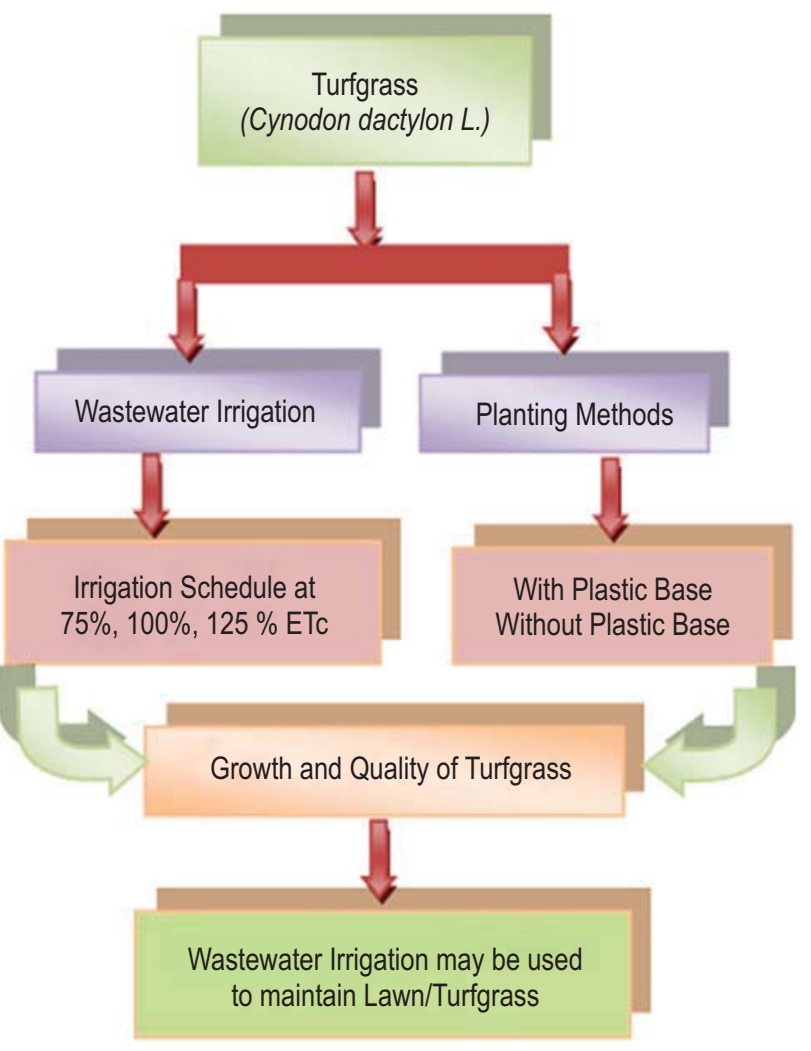
colour and quality were found

ranging between 6.5 to 8.0 (acceptable rating is 5) for most of months of the year excepting 3 winter months (December, January and February) in each year. In general, turfgrass grown under plastic base planting and irrigated at $125 \%$ ETc were observed to be associated with higher quality/colour.

Interpretation : Leaf firing, colour, quality and traffic tolerance of turfgrass was not affected by the wastewater irrigations practices. Plastic base planting and irrigation at $125 \%$ ETc may appreciably be enhanced by the appearance of turfgrass. 


\section{Introduction}

A continuous population growth in developing countries such as India has caused an increase in consumption of existing fresh water resources. This population increase has not only increased freshwater demand but has also increased the volume of wastewater generated due to diversion of larger amounts of freshwater into non-irrigation sectors such as domestic, commercial and industrial, which generate greater volumes of wastewater (Quian and Mecham, 2005; Qadir et al., 2007). Thus, there is an urgent need to conserve and protect freshwater and to utilize the generated wastewater (Gan etal., 2006; Pescod, 1992). Moreover, use of wastewater for irrigation may be a viable strategy for coping with shortages and/or the rising cost of fresh water in arid and semi-arid regions and in highly populated metropolitan areas (Harivandi, 2000). Moreover, the farmers of urban and peri-urban areas are deliberately using wastewater for irrigation as it provides nutrients or is more reliable or cheaper than other water sources (Keraita and Drechsel, 2004). Despite farmer's good reasoning, this practice can severely harm human health and the environment (Qadir et al., 2007) not only due to the associated pathogens, but also heavy metals and other undesirable constituents depending on the source (WHO, 2006). Additionally, farmers, consumers and some government agencies in many countries are not fully aware of the potential impacts of irrigation with wastewater (Qadir et al., 2010). However, the idea of using municipal wastewater for irrigating lawn/ turfgrass and other landscape plants is new and probably a bit unsettling to most people. Bermudagrass (Cynodon dactylon L.) is one of the most widely used turfgrass in tropical and subtropical regions in the world (McCarty and Miller, 2002). Moreover, the parks, golf courses, cemeteries and other venues of non-food, urban horticulture will be better able to compete for wastewater as compared to fresh water in future (Harivandi, 1994 and 2012). Moreover, several other arguments which favor the use of wastewater in turfgrass as compared to its use in food crops. First, wastewater contains higher quantities of nutrients and turfgrass in particular can absorb relatively large amounts of nutrients. It may greatly decrease the chances of ground-water contamination by wastewater irrigations. Second, turfgrass is a continuous growing plant species and wastewater is also produced continuously, therefore, it may sustain the supply and demand of wastewater for irrigating turfgrass. Third, wastewater is produced adjacent to cities where turfgrass are planted, thus it may minimize the transportation cost. And finally, soil-related chemical problems that might develop due to the use of wastewater will have a smaller social and economic impact if they develop where turfgrass are cultivated than if they develop where food crops are grown (Harivandi et al., 1992). Hence, it is clear that the turfgrass or lawn grass may be the best plants for wastewater irrigation. Besides, due to dense plant canopy and active root systems, turfgrass landscapes are increasingly being viewed as environmentally desirable disposal sites for wastewater (Anderson et al., 1981). It is necessary to have the knowledge about the impact of wastewater irrigation on turfgrass performance under particular soil type, turfgrass species and climate conditions. Most research addressing these issues have been conducted in the United States of America where the soil type, turfgrass species and climate conditions are quite different from Indian condition. The present study was therefore undertaken to study the Impact of varied wastewater irrigation schedules and planting methods on growth and quality of turfgrass (Cynodon dactylon L.) under Indian climatic and soil conditions.

\section{Materials and Methods}

A field experiment was conducted at Indian Agricultural Research Institute (IARI) research farm, New Delhi, India during 2013-16. The study area being a part of the $6^{\text {th }}$ Agro-Climatic Region/Zone (Trans-Gangetic Plains Region) and $4^{\text {th }}$ AgroEcological Region (Hot semi-arid eco-region with alluvium derived soil) of India has subtropical and semi-arid climate with hot dry summer and cold winter. The long-term (past 30 years) average annual rainfall was $710 \mathrm{~mm}$, of which about $75 \%$ was received in the monsoon/ rainy (wet) season during June-September. Soil of the experimental site was sandy loam. Soil $\mathrm{pH}_{2}(7.65)$ and $\mathrm{EC}_{2}\left(0.28 \mathrm{dSm}^{-1}\right)$ were optimum. Mean soil organic carbon (0.35\%), available $\mathrm{N}\left(126 \mathrm{~kg} \mathrm{ha}^{-1}\right)$ and available $\mathrm{P}$ $\left(28 \mathrm{~kg} \mathrm{ha}^{-1}\right)$ were low, whereas available $\mathrm{K}\left(282 \mathrm{~kg} \mathrm{ha}^{-1}\right)$ was medium. Bulk density of soil was $1.54 \mathrm{mg} \mathrm{m}^{-3}$ at a depth of $0-30$ $\mathrm{cm}$. The experiment was laid out in randomized block design with three replications and eight treatments viz T-1: Groundwater irrigation at $100 \%$ ETc under normal planting; T-2 : Groundwater irrigation at $100 \%$ ETC under plastic base planting; T-3: Wastewater irrigation at $100 \%$ ETc under normal planting; T-4: Wastewater irrigation at $100 \%$ ETc under plastic base planting; T-5 : Wastewater irrigation at $125 \%$ ETc under normal planting; T-6 : Wastewater irrigation at $125 \%$ ETc under plastic base planting; T-7 : Wastewater irrigation at $75 \%$ ETc under normal planting and T-8 : Wastewater irrigation at $75 \%$ ETc under plastic base planting. The unit depth of irrigation was taken as $50 \mathrm{~mm}$. Crop evapotranspiration (ETC) was taken as product of reference evapotranspiration $\left(E_{0}\right)$ and crop coefficient $(K c)$ values. Reference evapotranspiration $\left(\mathrm{ET}_{0}\right)$ was estimated by using $\mathrm{FAO}$ CROPWAT 8.0 model on daily basis. Crop coefficient $(\mathrm{Kc})$ value of 0.85 was taken from Food and Agriculture Organization (FAO) website. A fertilizer dose of 200:200:100 kg NPK ha ${ }^{-1}$ was applied. Turfgrass or Bermuda grass (Cynodon dactylon L.) was planted in May, 2013 by dibbling method with a spacing of $10 \mathrm{~cm} \times 10 \mathrm{~cm}$. Whole ground of the plot was covered full of turfgrass in the month of September, 2013. The observations were recorded on leaf firing, colour, quality and traffic tolerance of turfgrass as per procedure followed by National Turfgrass Evaluation Programme (NTEP, 2006; Shearman and Morris, 1998), USA. Leaf firing was estimated as percent of chlorotic leaf area with $0 \%$ corresponding to no leaf firing and $100 \%$ brown leaves. Turf colour and quality were estimated based on a scale of 1-9, with 9 as green, dense and uniform turf, and 1 as thin and completely brown turf (Uddin et al., 2011). Traffic tolerance is the combination of wear and compaction stress that occurs whenever a turf is exposed to foot or vehicular traffic. Therefore, the traffic tolerance were also 
estimated based on visual ratings of $1-9$ with 1 being no tolerance or $100 \%$ wear injury, and 9 being complete tolerance or no injury (Alshammary et al., 2003).

\section{Results and Discussion}

The differences regarding leaf firing, colour/quality and traffic tolerance of turfgrass among the treatments were not significant (Fig. 1, 2 \& 3). It indicated that there were no adverse impact of wastewater irrigation as compared to groundwater irrigation with or without plastic base planting at different irrigation schedules on growth, colour/quality and traffic tolerance of turfgrass. Qian and Meecham (2005) also reported a good appearance of turfgrass with both surface water and recycled wastewater irrigation. Moreover, several other studies which support that use of wastewater irrigation in turf grass could be an alternative to fresh water irrigation and also confirm that treated wastewater can be used for turf grass irrigation with a minimal environmental impact (Wu et al., 1996; Barton et al., 2005; Menzel and Broomhall, 2005; Lockett, 2008; Castro et al., 2011). As per monthly observations on leaf firing, it was observed that the higher leaf firing was observed in winter months whereas lower percentage of leaf firing was in summer months. It was further observed from Fig. 1 that the leaf firing in turfgrass was inversely proportionate to the length of sunshine hours. This was may be due to because of minimum length of sunshine hours promoted the turfgrass plants to go in dormancy state which showed the browniness or leaf firing. In general, turfgrass grown on plastic base planting and irrigated with wastewater at $125 \%$ ETc were observed to be associated with less leaf firing, whereas the difference among the treatments were statistically not significant. Ratings observed on turf colour were similar to ratings on turf quality. Hence, it is clear from Fig. 2 that the differences regarding turf colour and quality among the treatments were not significant. However, the ratings on turf colour and quality were observed higher than the acceptable rating, which is 5 as per the guidelines of National Turfgrass Evaluation Programme of USA (NTEP-USA, 2006) and Alshammary et al. (2003), in the summer months (April, May, June) and lower ratings $(<5.0)$ were observed during the winter months (December, January and February) in each year of experimentation (2013-16). Appreciably, higher ratings on turf colour and quality were associated with plastic base planting and wastewater irrigation scheduled at 125\% ETc.. However, the impact of wastewater irrigations scheduled and applied at different ETc with or without plastic base planting on turf colour and quality were statistically at par. This may be due higher nutrients potential of wastewater. Lockett et al. (2008) also reported that leaf xylem water potentials and color of turfgrass/golf courses grass were not significantly different with fresh and wastewater irrigations. The lower ratings on turf colour and quality in the winter months may be due low temperature and less bright sunshine hour. Harivandi (1992; 2004) observed a good growth and quality of turfgrass in wastewater irrigated plots. Leinauer et al. (2012) stated that all turfgrasses can maintain acceptable quality for a certain period of time when irrigation is less than $100 \%$ ETc, deficit irrigation, but to maintain a best turf quality for a long period of time, irrigation should be scheduled at more than 100\% ETc. Turfgrasses survive drought stress by means of drought resistance mechanisms or by successful recovery from long term water deficits (Devitt et al., 1992). However, deficit irrigation is only effective if turf areas receive sufficient rainfall to occasionally recharge the soil profile (Shearman, 2008). It is

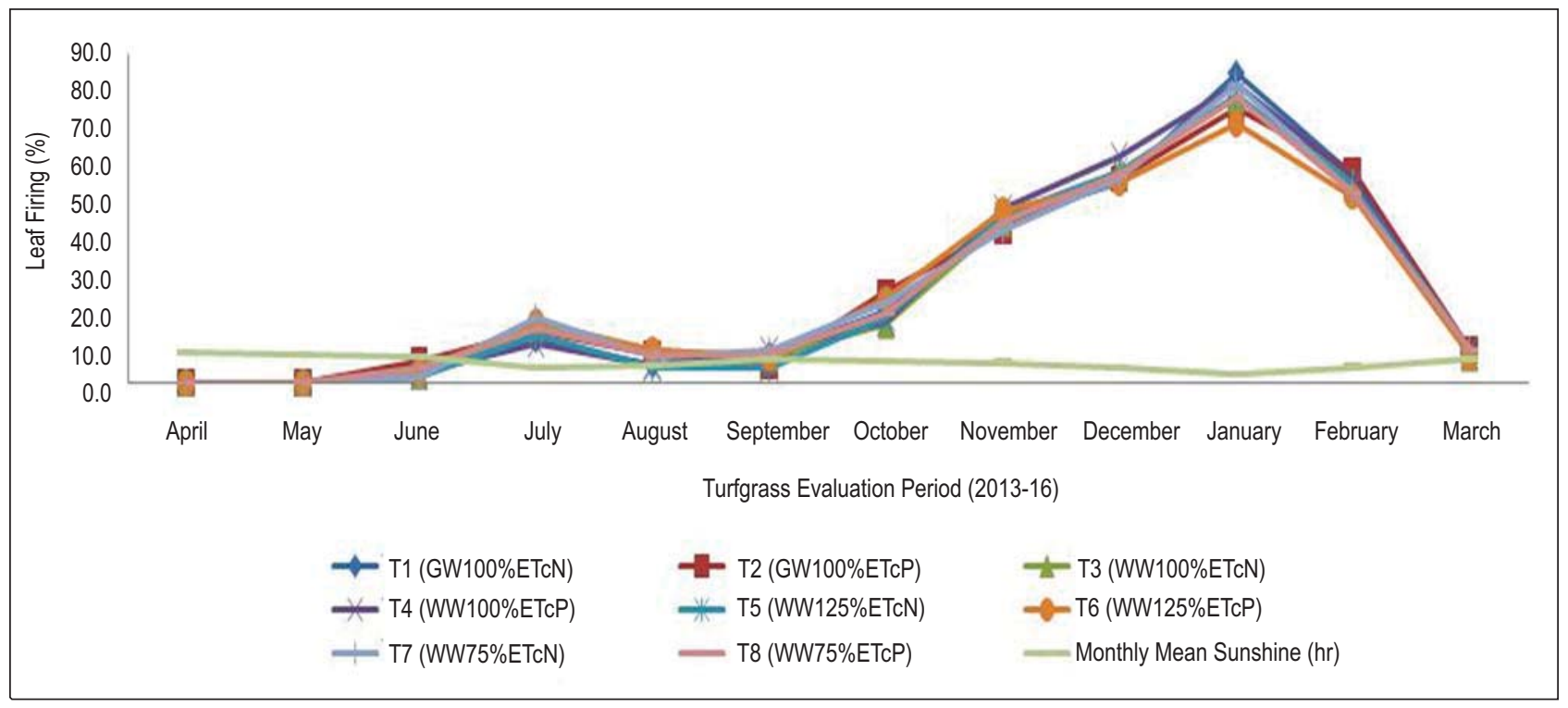

Fig. 1 : Impact of wastewater irrigations and planting methods on leaf firing in turfgrass (pooled data of 3 years) 


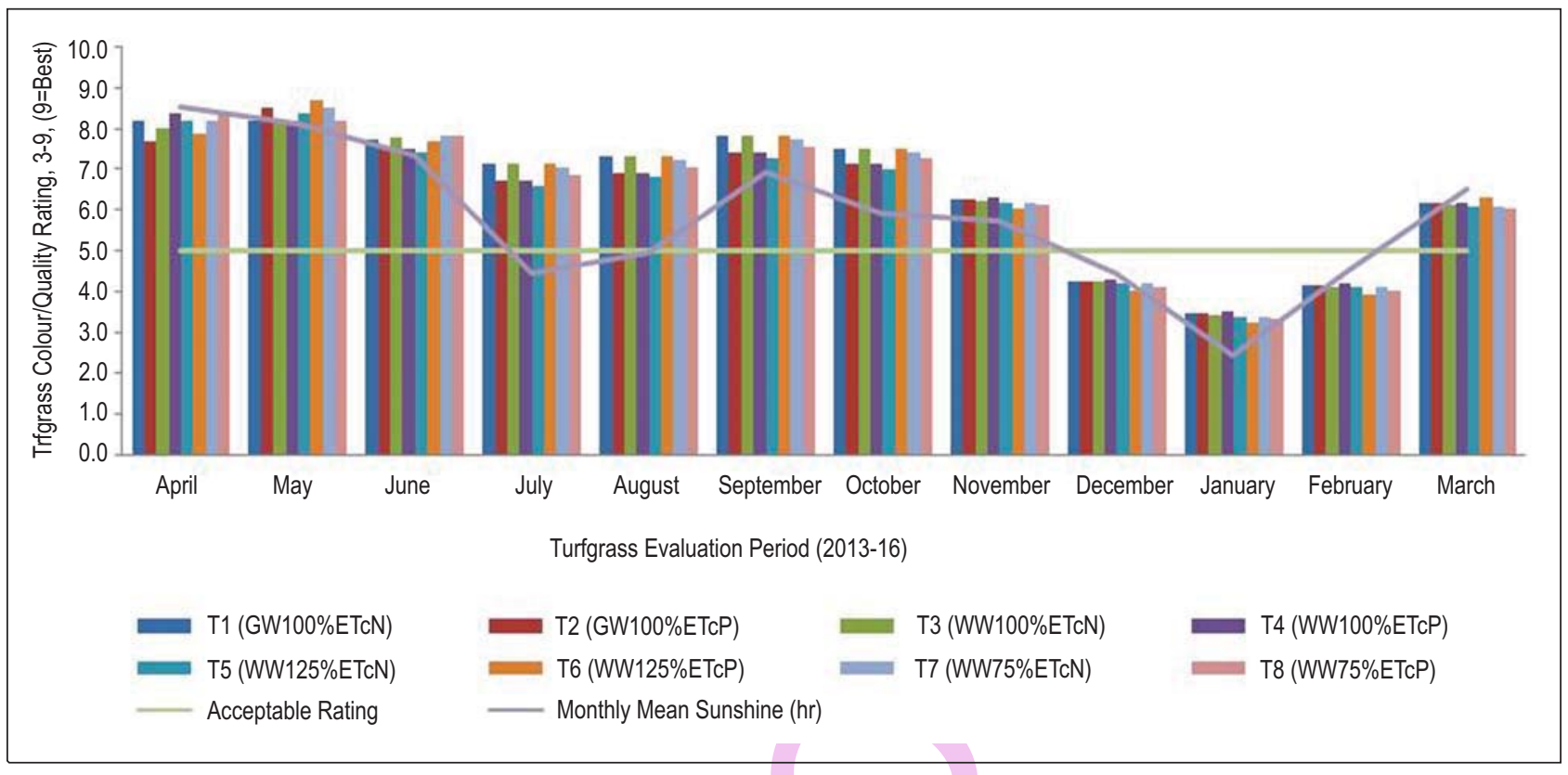

Fig. 2 : Impact of wastewater irrigations and planting methods on colour and quality of turfgrass (pooled data of 3 years)

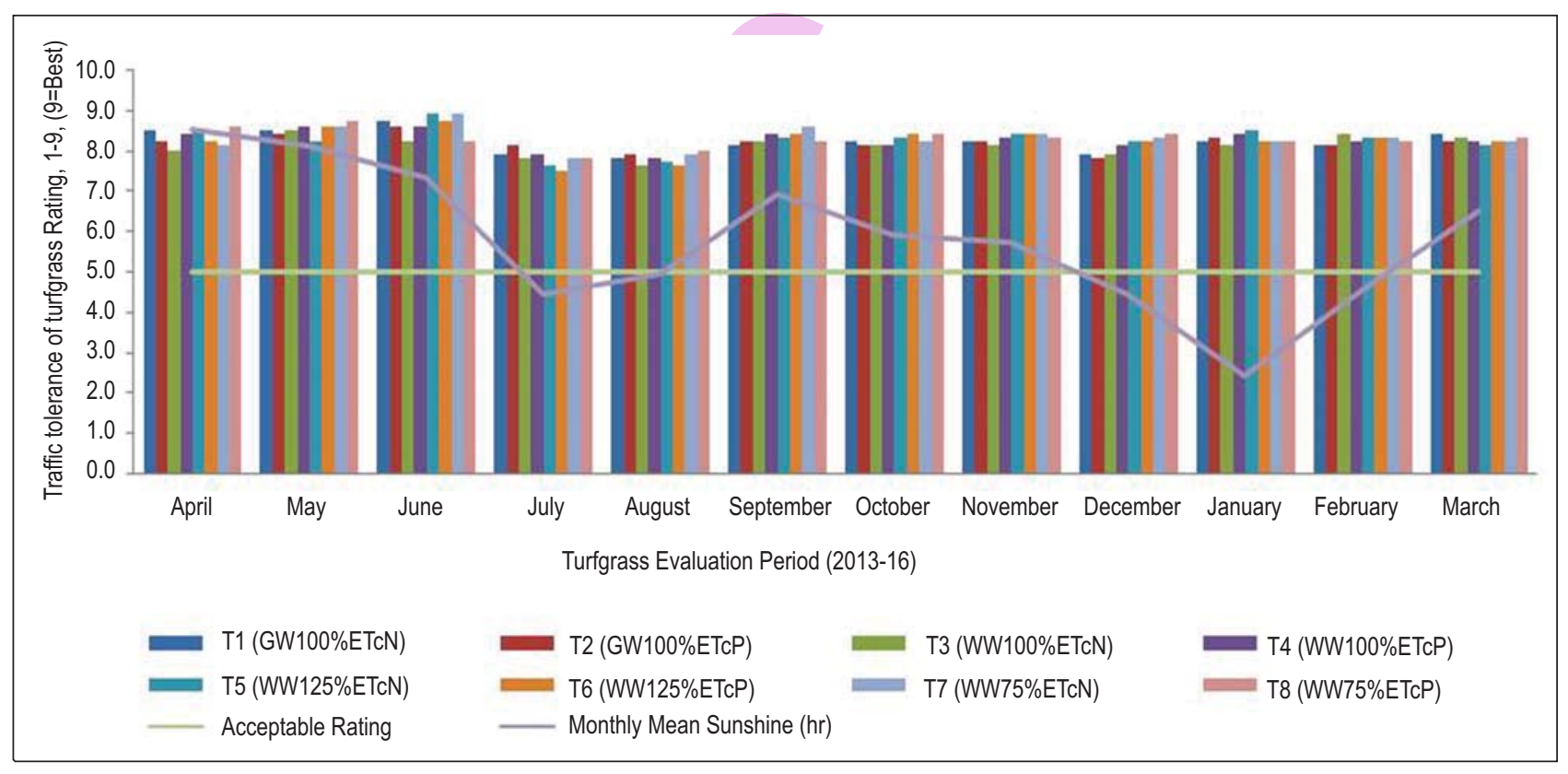

Fig. 3 : Impact of wastewater irrigations and planting methods on traffic tolerance of turfgrass (pooled data of 3 years)

also clear from Fig. 3 that the traffic tolerance ratings were more than 7.5 in all the treatments and months. This may be due to nature of Bermuda grass which is a drought tolerance and hardy grass species. Samples and Sorochan (2007) also stated that Bermuda grass is a vigorous, low-growing turfgrass stand with high density and can withstand both traffic and drought stress.
The growth and quality of turfgrass under wastewater irrigation were observed almost similar to the groundwater irrigated turfgrass. However, human health implications parameters needs to be further assessed. Plastic base planting and irrigation at $125 \%$ ETc may appreciably enhance the general appearance of turf or lawn grass. 


\section{Acknowledgments}

Authors are indebted to the Indian Council of Agricultural Research and ICAR-Indian Agricultural Research Institute, New Delhi for financial support under In-house Research Project. Authors are also thankful to Director, IARI and Project Director, WTC for grant of permission to conduct the present study.

\section{References}

Alshammary, S.F., Y.L. Qoin and S.J. Walner: Growth responses of four turfgrass species to salinity. Agril. Water Manag., 66, 97-111 (2003).

Anderson, E.L., I.L. Pepper and W.R. Kneebone: Reclamation of wastewater by means of a soil-turf filter-1: Removal of N. J. Water Poll. Cont. Fed., 53, 1402-1407 (1981).

Barton, L., L.A. Schipper, G.F. Barkle, M. McLeod, T.W. Speir, M.D. Taylor, A.C. McGill, A.P. Van Schaik, N.B. Fitzgerald and S.P. Pandey: Land application of domestic effluent on to four soil types: plant uptake and nutrient leaching. J. Environ. Qual., 34, 635-643 (2005).

Castro, E., M.P. Manas and J.D.L. Heras: Effects of wastewater irrigation on soil properties. Water Sci. Tech., 63, 1679-1688 (2011).

Devitt, D.A., R.L. Morris and D.C. Bowman: Evapotranspiration, crop coefficients and leaching fractions of irrigated desert turfgrass systems. Agron. J., 84, 717-723 (1992).

Gan, J.S., F. Bondarenko, W. Ernst, S. Yang, B. Ries and D.L Sedlak : Leaching of N-nitrosodimethylamine (NDMA) in turf grass soils during wastewater irrigation. J. Environ. Qual., 35, 277-284 (2006).

Harivandi, M.A.: Wastewater quality and treatment plants. In: Wastewater reuse for golf course irrigation. Lewis Publishers, Chelsea, Minnesota, U.S.A., pp. 106-129 (1994)

Harivandi, M.A., J.D. Butler and L. Wu: Salinity and turfgrass culture. In: Turfgrass. Series No. 32, (Eds.: D. V. Wadington, R. N. Carrow and R. C. Shearman) American Society of Agronomy, Madison, Wisconsin, U.S.A.,pp. 207-229(1992)

Harivandi, M.A.: Evaluating recycled waters for golf course irrigation. USGA Green Sec. Rec., 42, 25-29 (2004).

Harivandi, M.A. : Irrigating turfgrass and landscape plants with municipal recycled water. Acta Horti., 537, 667-703 (2000).

Harivandi, M.A.: Irrigating turfgrasses with municipal reclaimed water. Acta Horti., 938, 95-103 (2012).

Keraita, B.N. and P. Drechsel: Agricultural use of untreated urban wastewater in Ghana. In : Wastewater Use in Irrigated Agriculture (Eds.: C.A. Scott, N.I. Faruqui and L. Raschid-Sally). CABI Publishing, Wallingford, UK, pp. 101-112 (2004).
Leinauer, B., M. Serena, M. Schiavon and E. Sevostianova: Water demands and water conservation strategies in turfgrass management. Acta Horti., 938, 113-120 (2012)

Lockett, A.M. : Impact of reuse water on golf course oil and turf grass parameters monitored over a 4.5 year period. Hort. Sci., 43 , 1942-2274 (2008).

Lockett, A.M., D.A. Devitt and R.L. Morris: Impact of reuse water on golf course soil and turfgrass parameters monitored over a 4.5-year period. Hort Sci., 43, 2210-2218 (2008).

McCarty, L.B. and G. Miller: Managing bermudagrass turf. Sleeping Bear Press, Chelsea, Michigan (2002).

Menzel, C.M. and P. Broomhall : Recycled water : Good for parks, gardens and the environment. Acta Horti., 694, 191-196 (2005).

NTEP-USA: Bermudagrass progress report no. 07-06. National Turfgrass Evaluation Program (NTEP). Bethesda, Maryland, U.S.A. (2006).

Pescod, M.B.: Wastewater treatment and use in agriculture. FAO. Irrigation and drainage. Paper 47 (1992).

Qadir, M., D. Wichelns, L. Raschid-Sally, P.G. McCornick, P. Drechsel, A. Bahri and P.S. Minhas : The challenges of wastewater irrigation in developing countries, Agril. Water Managem., 97, 561-568 (2010).

Qadir, M., D. Wichelns, L. Raschid-Sally, P.S. Minhas, P. Drechsel, A. Bahri and P. McCornick : Agricultural use of marginal-quality water-opportunities and challenges. In : Water for Food, Water for Life: A Comprehensive Assessment of Water Management in Agriculture (Eds.: D. Molden). Earth scan, London, UK (2007).

Qian, Y.L. and B. Meecham: Long-term effects of recycled wastewater irrigation on soil chemical properties on golf course fair-ways. Agron. J., 97, 717-721 (2005).

Samples, T. and J. Sorochan: Bermudagrass. University of Tennessee Cooperative Extension Bulletin W159-A. University of Tennessee, Knoxville (2007)

Shearman, R.C. and K.N. Morris: NTEP Turfgrass Evaluation Workbook. NTEP Turfgrass Evaluation Workshop, Beltsville, MD, p. 5 (1998).

Shearman, R.C.: Turfgrass cultural practices for water conservation. In: Water quality and quantity issues for turfgrasses in urban landscapes (Eds.: J.B. Beard and M.P. Kenna). Council for Agricultural Science and Technology, Ames, IA, pp. 205-222 (2008).

Uddin, M.K., A.S. Juraimi, M.R. Ismail, R. Othman and A.A. Rahim: Relative salinity tolerance of warm season turfgrass species. J. Environ. Biol., 32, 309-312 (2011).

WHO: Guidelines for the safe use of wastewater excreta and greywater. World Health Organization (2006).

Wu, L., J. Chen, P. Mantgem and A.M. Harivandi: Regenerant wastewater irrigation and ion uptake in five turfgrass species. $J$. Plant Nutri., 19, 1511-1530 (1996). 